\title{
ANALISIS NARASI TOLERANSI BERAGAMA DALAM FILM 99 CAHAYA DI LANGIT EROPA
}

\author{
Oleh: \\ Yohandi \\ Universitas Ibrahimy Situbondo \\ yohandi1986@gmail.com
}

\begin{abstract}
:
99 Cahaya di Langit Eropa is one of the most inspiring movies, especially in understanding and interpreting the importance of maintaining unity in diversity. This movie teaches us about the importance of tolerance for survival in the present and future. This is important so that peoples can interpret and take lessons and moral messages from this film. This research was conducted using Todorov's narrative analysis method with the paradigm of constructivism and philosophical approach. The subject of this study is movie of 99 Cahaya di Langit Eropa, while the object of this research is religious tolerance. The technique of collecting data is with Archival Records techniques from data sources in the form of movie of 99 Cahaya di Langit Eropa.The results of this study can be concluded that in analyzing the contents of the narrative in the movie of 99 Cahaya di Langit Eropa with Tzvetan Todorov's model divided into three parts: 1) Initial Flow, 2) Middle Flow, 3) Final Flow and also four values of religious tolerance displayed by the characters, namely: 1 ) Recognizing the Rights of Everyone, 2) Respecting the Beliefs of Others, 3) Agree in Disagreement, and 4) Understanding each other. So this movie can be a medium in preaching with the meaning of religious tolerance.
\end{abstract}

Keywords: Analisis Narasi, Toleransi Beragama, Film

\section{A. Pendahuluan}

Masalah toleransi pada dasarnya berkaitan dengan problem yang terbesar dalam keberagaman manusia, yaitu kesadaran antarumat beragama akan keniscayaan pluralitas. ${ }^{1}$ Hal ini menjadi perhatian penting mengingat permasalahan toleransi merupakan refleksi dari keberagaman dari pemeluk agama ketika berhadapan dengan keniscayaan tersebut. Tidak mengherankan apabila agama bisa tampil dalam ambiguitas yang berlawanan. Toleransi pada dasarnya merupakan salah satu bentuk dan 169.

${ }^{1}$ Dadang Kahmad, Sosiologi Agama, (Bandung: PT. Remaja Rosdakarya, 2000), hlm. 
akomodasi sebagai suatu usaha manusia dalam mencapai kestabilan dalam masyarakat tanpa adanya perselisihan. ${ }^{2}$ Toleransi juga mengarahkan kepada terbentuknya asimilasi dalam suatu masyarakat bila didukung oleh komunikasi yang intens. ${ }^{3}$

Munculnya berbagai anggapan bahwa konflik yang terjadi di dunia ini disebabkan karena adanya keyakinan antara manusia yang satu dengan yang lainnya, agama seolah menjadi motor penggerak berbagai konflik dan kerusuhan. Pandangan demikian di sisi lain seolah-olah menyodorkan bahwa ajaran agama yang satu dengan yang lainnya memang bertentangan dan konflik yang terjadi di masyarakat merupakan konsekuensi logis dari perbedaan tersebut. Pendek kata konflik agama di masyarakat dipandang sebagai cerminan perbedaan iman dan interpretasi agama. ${ }^{4}$

Sungguh tragis jika manusia selalu hidup di zaman yang penuh kekerasan atas nama agama. Konflik yang terjadi di masyarakat ditangkap sebagai cerminan dari kesadaran keberagamaannya. Dengan pemikiran seperti itu maka wajarlah bahwa ajaran-ajaran agama kemudian dipakai untuk menghalalkan sebuah tindakan dalam penyelesaian konflik sosial masyarakat.

Akibatnya ini menyiratkan bagaimana ajaran agama mengukung manusia. ${ }^{5}$ Menurut Deddy Mulyana, pada hakekatnya agama Islam merupakan agama dakwah. Karena dakwah adalah kewajiban setiap muslim yang harus dilakukan secara berkesinambungan, yang bertujuan akhir mengubah perilaku manusia berdasarkan pengetahuan dan sikap yang benar, yakni untuk membawa manusia mengabdi kepada Allah secara total, mencintai Allah dan Rosul mereka lebih dari kecintaan mereka kepada diri mereka sendiri, seperti yang ditunjukkan para sahabat Nabi. Orang muslim yang telah memenuhi syarat berkewajiban melaksanakan tugas dakwah sesuai dengan kemampuan yang dimilikinya. ${ }^{6}$ Dalam Al-Qur'an surat Ali Imran ayat 104 Allah telah berfirman:

${ }^{2}$ Soejono Soekanto, Sosiologi Suatu Pengantar, (Jakarta: Rajawali Press, 2002), hlm. 78.

${ }^{3}$ Ibid, hlm. 83.

${ }_{4}^{4}$ Moeslim Abdurrahman, Islam Sebagai Kritik Sosial, (Jakarta: Erlangga, 2003), hlm. 61.

${ }^{5}$ Ibid, hlm. 61.

${ }^{6}$ Deddy Mulyana, Nuansa-Nuansa Komunikasi Politik dan Budaya Komunikasi Masyarakat Kontemporer, (Bandung; PT. Remaja Rosdakarya, 2001). hlm. 54.

308 JURNAL LISAN AL-HAL 


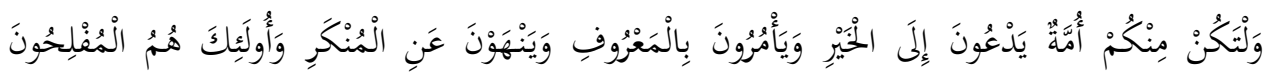

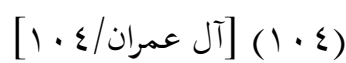

"Dan hendaklah ada di antara kamu segolongan umat yang menyeru kepada kebajikan, menyuruh kepada yang ma'ruf dan mencegah dari yang munkar merekalah orang-orang yang beruntung."

Itulah salah satu dasar hukum mengapa agama Islam itu wajib disebar luaskan. Dengan demikian dakwah merupakan upaya untuk merubah suatu keadaan menjadi keadaan yang lebih baik sesuai tolak ukur ajaran Islam hingga tercipta masyarakat yang sakinah, termasuk menetralnya adanya konflik yang lahir dengan latar belakang agama Islam khusunya. Dalam perkembangannya dakwah mengalami berbagai masalah. Dalam rangka menghadapi masalah-masalah dakwah yang sangat berat dan meningkat tersebut, penyelenggaraan dakwah tidak dapat dilakukan oleh seorang atau secara individual saja namun dapat dibantu dengan media cetak maupun media audio-audio visual.

Dalam perkembangannya film hadir sebagai media yang tidak saja mengandung hiburan namun juga merupakan pernyataan budaya yang melakukan komunikasi pesan dari pembuat film kepada seluruh penonton ke seluruh daerah atau nasional, bahkan dunia. ${ }^{8}$ Bahasa film adalah kombinasi antara bahasa suara dan bahasa gambar, melalui pengalaman mental dan budaya yang dimilikinya, penonton berperan aktif secara sadar maupun tidak untuk memahami sebuah film. ${ }^{9}$ Sehingga maksud film yang ingin disampaikan oleh seorang sutradara dapat tersampaikan dan dipahami oleh penonton.

Keberadaan suatu film tidak terlepas dari latar belakang pendidikan, latar belakang lingkungan, latar belakang pengetahuan, latar belakang pengalaman pribadi, dan juga latar belakang agama. Sehingga karya sastra dalam hal ini film memiliki kekhasan tersendiri. Begitu juga latar belakang film"99 Cahaya di Langit Eropa" yang kental dengan nilai toleransi antarumat beragamanya. Film ini mencoba menghantarkan secara jernih dan kritis terhadap hal-hal yang berkaitan dengan toleransi antarumat beragama dengan mencoba melihat realitas yang ada di masyarkat dunia pada umumnya. Begitu juga film "99 Cahaya di Langit

${ }^{7}$ Departemen Agama RI, Al-Qur'an Dan Terjemahan, (Bandung: PT. Syaamil Cipta Media, 2004), hlm. 63.

${ }^{8}$ Karl Heider, National Culture On Screen, (Indonesia Cinema: University of Hawaii Press, 1991), hlm. 1.

${ }^{9}$ Himawan Prasista, Memahami Film, (Yogyakarta: Homerian Pustaka, 2008), hlm. 3. 
Eropa" yang menampilkan sebuah realitas sosial dengan latar belakang agama dengan berbagai masalah kehidupan. Film ini juga menampilkan bagaimana hubungan persaudaraan antar tokoh dilakukan, baik hak maupun kewajibannya kepada sesama maupun pemeluk agama lain.

Guntur Soeharjanto menyajikan pesan-pesan secara simbolik yang berhubungan dengan perbedaan dan toleransi. Saat menyaksikan film ini, kita bisa memperhatikan beberapa hal yang memang cukup menunjukkan bagaimana perbedaan agama seseorang sangat mempengaruhi hubungan antar manusia. Itu terlihat dari cara para tokoh film saling berkomunikasi untuk saling memahami dan menghormati antar sesama. Ini terlihat dari salam yang diucapkan, makanan halal yang disediakan untuk penduduk muslim, tempat beribadah hingga komunikasi antar tokoh yang Guntur Soeharjanto perlihatkan pada beberapa adegan dalam film tersebut.

\section{B. Kajian Naratif dalam Film}

Analisis naratif kerap digunakan untuk membongkar maksud ideologis sebuah karya. Analisis naratif adalah sebuah cara yang kuat dan bermanfaat untuk menjelajahi teks-teks media dan menemukan ideologi di balik struktur tersebut. ${ }^{10}$ Pada umumnya, teks-teks yang menjadi sasaran analisis naratif adalah film dan program televisi. Selain itu, analisis naratif masih menjadi landasan dalam bentuk-bentuk tradisional seperti novel, puisi, drama, lirik lagu, puisi dan cerita pendek.

Analisis tersebut melibatkan pemahaman serta pembacaan yang sangat cermat pada setiap narasi dengan cara bertitik tolak terhadap teks dan mengarah pada sebuah dugaan mengenai teks tersebut.11 Melalui analisis naratif, dapat memudahkan dalam menemukan berbagai macam temuan pada suatu narasi. Setelah itu, dapat terangkai sebuah penyataan yang berkenaan dengan apa yang dimaksudkan untuk dibuktikan, atau ditemukan kekeliruannya. Melalui analisis film ini, peneliti akan mengkajinya dari narasi dan teks dialog film 99 Cahaya Di Langit Eropa.

\section{Definisi Analisis Naratif}

Naratif berasal dari kata Latin narre, yang artinya "membuat tahu." Dengan begitu, naratif berhubungan dengan usaha untuk memberitahu sesuatu atau peristiwa. ${ }^{12}$ Teori naratif merupakan teori yang membahas

10 Jane Stokes, How To Do Media and Cultural Studies (Panduan untuk Melaksanakan Penelitian dalam Kajian Media dan Budaya), (Yogyakarta: PT. Bentang Pustaka, 2003), hlm. 73.

11 Ibid, hlm. 75.

12 Eriyanto, Analisis Naratif: Dasar-dasar dan penerapannya dalam Analisis Teks

$310 \mid$ JURNAL LISAN AL-HAL 
tentang perangkat dan konvensi dari sebuah cerita. Cerita yang dimaksud bisa dikategorikan fiksi atau fakta yang sudah disusun secara berurutan. Hal ini memungkinkan khalayak untuk terlibat dalam cerita tersebut.

Menurut Branston and Stafford, naratif terdiri atas empat macam: 1) naratif menurut Todorov, memiliki alur awal, tengah, dan akhir, 2) sedangkan menurut Propp, suatu cerita pasti memiliki karakter tokoh, 3) sementara menurut Levis-Strauss, suatu cerita memiliki sifat-sifat yang berlawanan, 4) terakhir naratif Joseph Campbell, yang kaitannya membahas naratif dengan mitos. ${ }^{13}$ Namun, peneliti hanya menggunakan teori naratif menurut Todorov, karena film ini masuk kategori drama, ini akan digunakan di Bab empat nanti.

\section{Teori Naratif Menurut Tzvetan Todorov}

Tzvetan Todorov; mengatakan bahwa semua cerita dimulai dengan "keseimbangan" di mana beberapa potensi pertentangan berusaha "diseimbangkan" pada suatu waktu. Teorinya mungkin terdengar seperti klise bahwa cerita punya awal, pertengahan dan sebuah akhir. Namun, keseimbangan menandai sebuah keadaan, dalam sebuah cara-cara. ${ }^{14}$

Naratif berisi penjelasan bagaimana cerita disampaikan, bagaimana materi dari suatu cerita dipilih dan disusun untuk mencapai efek tertentu kepada khalayak. ${ }^{15}$ Naratif adalah proses dan efek dari merepresentasikan waktu dalam teks. ${ }^{16}$ Setiap naratif memiliki sebuah plot atau alur yang didasarkan pada kesinambungan peristiwa dalam naratif itu dalam hubungan sebab akibat.

Ada bagian yang mengawali naratif, ada bagian yang merupakan perkembangan lebih lanjut dari situasi awal, dan ada bagian yang mengakhiri naratif itu. Alurlah yang menandai kapan sebuah naratif itu mulai dan kapan berakhir. ${ }^{17}$ Menurut Todorov, pada bagian awal ada interaksi situasi dasar dan kemudian di tengah menimbulkan konflik dan pada akhirnya biasanya akan berakhir bahagia. Tentu saja itu melalui intervensi dari produk yang akan dijual. Tidak perlu dipersoalkan, bahwa

Berita Media, (Jakarta: Kencana Prenada Media Group, 2013), hlm. 1.

13 Gill Branston and Roy Stafford, The Media Student's, (London: Routledge, 2003), hlm. 56-57.

14 Ibid, hlm. 36.

15 GillBranston and Roy Stafford, The Media Student's, hlm. 38.

16Tony Thwaites, dkk, Introducing Cultural and Media Studies, (Yogyakarta:Jalasutra, 2009), hlm. 174.

17 Ibid, hlm. 36. 
akhir naratif masih menimbulkan persoalan baru lagi. Alur ditandai oleh puncak atau klimaks dari perbuatan dramatis dalam rentang laju naratif. skematis alur dapat digambarkan sebagi berikut.

Gambar. 1.1 Diagram Alur Film ${ }^{18}$

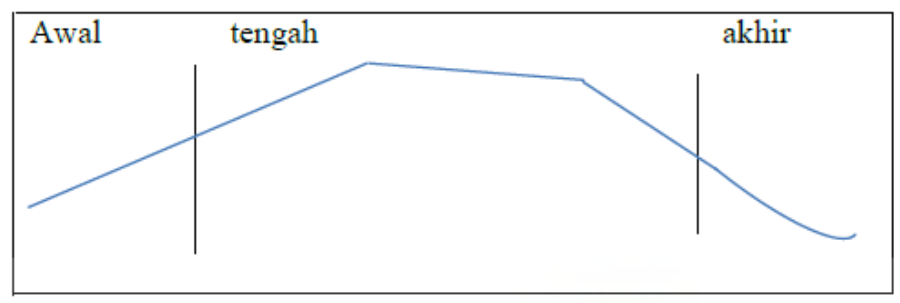

Banyak pendapat dan kritikan mengenai pembagian waktu dalam sebuah cerita, tetapi kritikan tidak bisa meniadakan pembagian waktu itu. Misalnya, ada pendapat yang mengatakan, bahwa sebenarnya apa yang disebut "penyelesaian" itu sebenarnya tidak ada, karena akhir dari suatu kejadian atau peristiwa akan menjadi awal dari kejadian yang lain, atau akhir dari tragedi itu merupakan sebuah diskusi, yang pada gilirannya menjadi bagian pendahuluan dari kisah berikutnya. ${ }^{19}$ Sebab itu, naratif harus diberi batasan yang lebih jelas, yaitu rangkaian tindakan yang terdiri atas tahap-tahap yang penting dalam sebuah struktur yang terikat oleh waktu. Di mana waktu ini dibagi menjadi tiga waktu, yaitu bagian awal atau pendahuluan, bagian tengah atau perkembangan, dan bagian akhir atau bagian peleraian. Berikut rincian dari ketiga bagian tadi sebagai berikut:

a. Alur Cerita Awal

Bagian pendahuluan menentukan daya tarik dan selera pembaca atau penonton terhadap bagian-bagian berikutnya, maka penulis harus menggarapnya dengan sungguh-sungguh secara seni. Bagian pendahuluan harus merupakan seni tersendiri yang berusaha menjaring minat dan perhatian pembaca atau penonton.

b. Alur Cerita Tengah

Bagian tubuh cerita sudah melepaskan dirinya dari situasi umum atau situasi awal, dan sudah mulai memasuki tahap konkritisasi. ${ }^{20}$

18 Gorys Keraf, Argumentasi dan Naratif, (Jakarta: PT. Gramedia Pustaka Utama, 1997), hlm. 145.

19 Ibid, hlm. 146.

20 Ibid,56. 
Konkritisasi diungkapkan dengan menguraikan secara terperinci peranan semua sistem naratif, perbuatan atau tindak-tanduk tokoh-tokoh, interelasi antara tokoh-tokoh dan tindakan mereka yang menimbulkan benturan kepentingan. Konflik yang ada hanya dapat dimengerti dan dipahami dengan baik, jika situasi awal dalam bagian pendahuluan sudah disajikan secara jelas.

c. Alur Cerita Akhir

Akhir suatu cerita bukan hanya menjadi titik yang menjadi pertanda berakhirnya suatu tindakan. Lebih tepat jika dikatakan, bahwa akhir dari perbuatan merupakan titik di mana tenaga-tenaga atau kekuatan-kekuatan yang diemban dalam situasi yang tercipta sejak semula membersit keluar dan menemukan pemecahannya. ${ }^{21}$

Secara sederhana, skema pembagian tiga waktu alur cerita dalam naratif dapat digambarkan sebagai berikut:

Gambar. 2.1 Skema pembagian tiga waktu dalam naratif ${ }^{22}$

\begin{tabular}{|lll|}
\hline $\begin{array}{l}\text { Ekulibrium } \\
\text { (Keseimbangan) }\end{array}$ & $\begin{array}{c}\text { Gangguan } \\
\text { (Kekacauan) }\end{array}$ & $\begin{array}{l}\text { Ekulibrium } \\
\text { (Keseimbangan) }\end{array}$ \\
\hline
\end{tabular}

\section{Tinjauan Tentang Toleransi Antarumat Beragama}

Toleransi mengarah kepada sikap terbuka dan mau mengakui adanya berbagai macam perbedaan, baik dari sisi suku bangsa, warna kulit, bahasa, adat-istiadat, budaya, bahasa, serta agama. Ini semua merupakan fitrah dan sunatullah yang sudah menjadi ketetapan Tuhan. Dalam pengkajian mengenai konsep toleransi secara teoritik menurut filsuf Amerika, Emerson. Ia menawarkan gagasan tentang "keyakinan subyektif (selfreliance)".

Menurut Mukti Ali, upaya yang tepat untuk menciptakan kerukunan antarumat beragama adalah dengan jalan agree in disagreement. Gagasan ini menekankan bahwa agama yang ia peluk itula agama yang paling baik. Walaupun demikian, ia mengakui diantara agama yang satu dengan agama-agama yang lainnya selain terdapat perbedaanperbedaan juga terdapat persamaan-persamaan. Pengakuan seperti ini akan membawa kepada suatu pengertian yang baik yang dapat

${ }^{21}$ Gill Branston and Roy Stafford, The Media Student's Book,154.

22 Tony Thwaites, dkk, Introducing Cultural and Media Studies (Yogyakarta:Jalasutra, 2009),184. 
menimbulkan adanya saling harga menghargai dan saling hormat menghormati antara kelompok-kelompok pemeluk agama yang satu dengan kelompok-kelompok penganut agama yang lain. ${ }^{23}$

Dasar-dasar toleransi dan kemerdekaan dalam beragama dalam Islam telah diatur dalam Al-Qur'an, berdasarkan Q.S. Al-Baqarah ayat 256 dan surat Al-Kafirun, yang menerangkan konsepsi penciptaan manusia dan kebebasan dalam memilih keyakinan. Istilah toleransi sendiri dalam bahasa inggris yaitu "tolerance" yang memiliki makna sikap membiarkan, mengakui dan menghormati keyakinan orang lain tanpa memerlukan persetujuan. ${ }^{24}$ Karena itu, agama Islam menurut hadist yang diriwayatkan oleh Bukhori, Rasulullah SAW. Pernah ditanya tentang agama yang paling dicintai oleh Allah, maka beliau menjawab: al-Hanafiyyah as-Samhah (agama yang lurus yang penuh toleransi), itulah agama Islam. ${ }^{25}$

\section{Prinsip-prinsip Toleransi Beragama}

Dalam melaksanakan toleransi beragama kita harus mempunyai sikap atau prinsip untuk mencapai kebahagiaan dan ketenteraman. Toleransi sebagai realitas juga dibentuk oleh nilai dalam masyarakat itu sendiri. Prinsip-prinsip toleransi antara lain menurut Umar Hasyim dalam bukunya yang berjudul Toleransi dan Kemerdekaan Beragama dalam Islam Sebagai Dasar Menuju Dialog dan Kerukunan Antar Beragama(Surabaya: Bina Ilmu, 1997) adalah:

Pertama, Mengakui hak setiap orang. Hak disini menyangkut pertama-tama adalah hak yang dimiliki individu-individu terhadap Negara maupun antar kelompok dan antar individu. Negara tidak boleh menghindari atau mengganggu individu dalam mewujudkan hak-hak yang ia milki. Contoh: hak beragama, hak mengikuti hati nurani, hak mengemukakan pendapat.

Kedua, Menghormati keyakinan orang lain. Landasan akan menghormati keyakinan orang lain adalah berdasarkan kepercayaan, bahwa tidak benar ada orang atau golongan yang bersikeras memaksakan kehendaknya sendiri kepada orang lain. Tidak ada orang atau golongan

23 Faisal Ismail, Pijar-Pijar Islam, Pergumulan dan Struktur, (Yogyakarta: LESFI 2002), 203.

${ }^{24}$ David G. Gularnic, Webste's World Dictionary of American Language, (Cleveland and New York: The world Publising Company, 1959), 779.

${ }^{25}$ Hadist ini diriwayatkan oleh Muhammad bin Ismail bin Ibrahim al-Bukhary, alJami'ah Shahihah, Kitab: Iman, (Kairo, Mesir: Maktah as-Salafiyah 1400 H), jld I,29.

$314 \mid$ JURNAL LISAN AL-HAL 
yang memonopoli kebenaran, dan landasan ini disertai catatan bahwa soal keyakinan adalah urusan pribadi masing-masing orang. ${ }^{26}$

Ketiga, Agree in Disagreement. Agree in Disagreement (setuju di dalam perbedaan) adalah prinsip yang selalu digunakan oleh A. Mukti Ali. Perbedaan tidak harus ada permusuhan, karena perbedaan selalu ada di dunia ini, dan perbedaan tidak harus menimbulkan pertentangan. ${ }^{27}$ Setiap pemeluk agama hendaknya meyakini dan mempercayai kebenaran agama yang dipeluknya merupakan suatu sikap yang wajar dan logis. Keyakinan akan kebenaran terhadap agama yang dipeluknya ini tidak akan membuat dia merasa eksklusif, akan tetapi justeru mengakui adanya perbedaanperbedaan agama yang dianut orang lain di samping tentu saja persamaan-persamaan dengan agama yang dipeluknya.

Keempat, Saling Mengerti. Tidak akan terjadi saling menghormati antara sesama manusia bila mereka tidak ada saling mengerti, saling anti dan saling membenci, saling berebut pengaruh adalah salah satu akibat dari tidak adanya saling mengerti dan saling menghargai.

\section{Macam-macam Toleransi}

Secara umum Masykuri Abdullah memetakan toleransi menjadi dua. Pertama, Toleransi Terhadap Sesama Agama. Toleransi beragama mempunyai arti sikap lapang dada seseorang untuk menghormati dan membiarkan pemeluk agama untuk melaksanakan ibadah mereka menurut ajaran dan ketentuan agama masing-masing yang diyakini tanpa ada yang mengganggu atau memaksakan baik dari orang lain maupun dari keluarganya sekalipun. ${ }^{28}$

Kedua, Toleransi Terhadap Non Muslim. Toleransi dalam pergaulan hidup antar umat beragama berpangkal dari penghayatan ajaran masingmasing. Menurut said Agil Al Munawar ada dua macam toleransi yaitu toleransi statis dan toleransi dinamis. Toleransi statis adalah toleransi dingin tidak melahirkan kerjasama hanya bersifat teoritis. ${ }^{29}$ Toleransi dinamis adalah toleransi aktif melahirkan kerja sama untuk tujuan bersama, sehingga kerukunan antar umat beragama bukan dalam bentuk

26 Umar Hasyim, Toleransi dan Kemerdekaan Beragama dalam Islam Sebagai Dasar Menuju Dialog dan Kerukunan Antar Beragama (Surabaya: Bina Ilmu, 1997), hlm. 24.

27 Umar Hasyim, Toleransi dan Kemerdekaan Beragama dalam Islam Sebagai Dasar Menuju Dialog dan Kerukunan Antar Beragama,(Surabaya: Bina Ilmu, 1997), hlm. 24.

28 Masykuri Abdullah, Pluralisme Agama dan Kerukunan dalam Keragaman (Jakarta: Penerbit Buku Kompas, 2001), hlm. 13.

${ }^{29}$ Ibid, hlm. 16. 
teoritis, tetapi sebagai refleksi dari kebersamaan umat beragama sebagai satu bangsa. ${ }^{30}$

\section{Tinjauan Umum tentang Film \\ 1. Film}

Film merupakan karya seni yang diproduksi secara kreatif dan mengandung suatu nilai baik positif ataupun negatif, sehingga mengandung suatu makna yang sempurna. Namun, terkadang makna yang terkandung dalam film tersebut itu kurang disadari oleh para penonton pada umumnya. Makna yang terkandung dalam suatu film, kita dapat melihat dari sistem-sistem pembentuk film itu sendiri. ${ }^{31}$

\section{Jenis dan Klasifikasi Film}

Pertama, Jenis-jenis film. Secara umum pembagian jenis film didasarkan atas cara bertuturnya, yakni naratif (cerita) seperti film fiksi dan non-naratif (non-cerita) seperti film documenter dan film eksperimental. Berikut penjelasan jenis-jenis film:

a. Film Dokumenter. Adalah film dengan penyajian fakta berhubungan dengan orang-orang, tokoh, peristiwa, dan lokasi yang nyata. Film dokumenter dapat digunakan untuk berbagai macam maksud dan tujuan seperti informasi atau berita, biografi, pengetahuan, pendidikan, sosial, politik (propaganda), dan lain-lain.

b. Film Fiksi. Adalah film yang menggunakan cerita rekaan di luar kejadian nyata, terkait oleh plot, dan memiliki konsep pengadegan yang telah dirancang sejak awal. Struktur cerita film juga terkait hukum kausalitas. Cerita fiksi sering kali di angkat dari kejadian nyata dengan beberapa cuplikan rekaman gambar dari peristiwa aslinya (fiksidokumenter).

c. Film Eksperimental. Adalah film yang berstruktur namun tidak berplot. Film ini tidak bercerita tentang apapun (anti naratif) dan semua adegannya menentang logika sebab akibat (antirasionalitas). ${ }^{32}$

Kedua, Klasifikasi film. Menurut Himawan pratista dalam buku Memahami Film, metode yang paling mudah dan sering digunakan untuk mengklasifikasi film adalah berdasarkan genre, yaitu klasifikasi dari

${ }^{30}$ Dyayadi, M.T., Kamus Lengkap Islamologi, (Yogyakarta : Qiyas, 2009), hlm. 614.

${ }^{31}$ Bordwell, David and Thompson Kristin.Film Art an Introduction, Fourth Edition (Singapore: McGraw-Hill Companies Inc, 2006), hlm. 118.

32 Himawan Pratista, Memahami Film, (Yogyakarta: Homerian Pustaka, 2008), hlm. 8.

316 JURNAL LISAN AL-HAL 
sekelompok film yang memilki karakter atau pola yang sama sebagai berikut:

a. Drama. Drama ini merupakan tema yang mengetengahkan aspek-aspek human interest, sehingga yang dituju adalah perasaan penonton untuk dapat meresapi setiap kejadian yang menimpa tokoh dalam adegan tersebut. Tema ini pula bisa dikaitkan dengan latar belakang kejadiannya. Jika kejadiannya tersebut di sekitar keluarga, maka disebut dengan drama keluarga.

b. Action. Pada istilah ini action seringkali berkaitan dengan adegan berkelahi, bertengkar, dan tembak-menembak. Sehingga, tema ini bisa dikatakan sebagai film yang berisi "pertarungan" atau "perkelahian" fisik yang dilakukan oleh peran protagonis dengan antagonis.

c. Komedi. Komedi ini merupakan tema yang sebaiknya bisa dibedakan dengan lawakan. Sebab, jika dalam lawakan biasanya yang berperan adalah para pelawak. Dalam komedi itu tidak dilakonkan oleh para pelawak, melainkan pemain film biasa saja. Inti dari tema komedi selalu menawarkan sesuatu yang membuat penontonnya tersenyum bahkan tertawa terbahakbahak. Biasanya juga, film yang berkaitan dengan komedi ini merupakan suatu sindiran pada fenomena sosial atau kejadian tertentu yang sedang terjadi.

d. Horor. Jika sebuah film menawarkan suasana yang menakutkan, menyeramkan, dan membuat penontonnya merinding, itulah yang disebut dengan film horor. Suasana horor dalam film itu bisa dibuat dengan cara animasi, special effect, atau bisa langsung diperankan oleh tokoh-tokoh dalam film tersebut.

e. Tragedi. Pada tema ini, tragedi menitik beratkan pada nasib manusia. Jika sebuah film dengan akhir cerita sang tokoh selamat dari kekerasan, perampokan atau bencana alam dan lainnya, bisa disebut dengan tragedi.

f. Drama Action. Tema ini merupakan gabungan dari dua tema, yaitu: drama dan action. Pada tema drama action ini biasanya menyuguhkan suasana drama dan juga adegan-adegan berupa "petengkaran fisik." Untuk menandainya, dapat dilihat dengan cara melihat alur cerita film. Biasanya film dimulai dengan suasana drama, lalu setelah itu alur meluncur dengan menyuguhkan suasana tegang, biasanya berupa pertengkaranpertengkaran.

g. Komedi tragis. Suasana komedi biasanya ditonjolkan terlebih dahulu, kemudian menyusul dengan adegan-adegan yang tragis. Suasana yang dibangun memang getir, sehingga penonton terbawa dengan emosinya dalam suasana tragis. Akan tetapi terbungkus dalam suasana komedi. 
h. Komedi horor. Komedi horor sama dengan seperti komedi tragis. Suasana komedi horor juga merupakan gabungan antara tema komedi dan horor. Biasanya film dengan tema ini menampilkan film horor yang berkembang, kemudian diplesetkan menjadi komedi.

i. Parodi. Tema parodi ini merupakan duplikasi dari tema film tertentu. Tetapi diplesetkan, sehingga ketika film parodi ditayangkan, para penonton akan melihat satu adegan film tersebut dengan tersenyum dan tertawa. Penonton berbuat demikian tidak sekedar karena film yang ditayangkan itu lucu, tetapi karena adegan yang ditonton pernah mucul di film-film sebelumnya. Tentunya para penikmat film parodi akan paham kalau sering menonton film, sebab parodi selalu mengulang adegan film yang lain dengan pendekatan komedi. Jadi, tema parodi itu berdime2nsi duplikasi film yang sudah ada, kemudian dikomedikan.

\section{E. Toleransi dalam film 99 cahaya dilangit eropa}

Untuk memahami bagaimana memaknai toleransi dalam film ini maka perlu penulis tampilkan beberapa dialog yang bisa dianalis dan memhami konsep toleransi dalam film tersebut

\section{Alur Awal}

Scane 1:

Leon :"Bu Endelman, Kara Mustafa orang Turki bukan?

Bu Endelman:"ya Leon, itu benar".

Leon :"Jadi seperti Ayse, jangan-jangan dia kakeknya Ayse".

Ayse : :"tidak, aku tidak kenal dia!".

Leon :"tapi kamu orang Turki, dan memakai kerudung seperti Kara Mustafa".

Ayse :"dia juga memakai tutup kepala,kenapa aku tidak?" (ayse menunjuk temannya yang juga memakai tutup kepala)

Bu Endelman :"cukup anak-anak! Ayse pakai penutup kepala karena dia seorang Muslim".

Leon :"Ooooo... Saya mengerti... tapi Kara Mustafa Seorang Muslim juga kan?"

Ayse :"Itu bohong!"

Bu Endelman :"Ayse, ini bukan tentang sejarah pribadimu, ini adalah sejarah dari tahun 1683, jadi tidak perlu dipermasalahkan".

Makna toleransi bergama dalam Scene ini adalah Agree in disagreement, telah terjadi dialog antara Mrs. Edelma, Ayse dan Leon 
dalam sebuah kelas yang kemudian terjadilah perdebatan kecil diantara Ayse dan Leon mengenai latar belakang agama Kara Mustafa dan Ayse yang sama. Mrs. Edelman pun pada akhirnya menengahi perdebatan mereka mengenai sejarah agama Kara Mustafa dan mengajarkan bahwa mereka harus menerima sejarah yang sudah terjadi dan tidak mempermasalahkannya.

Dalam scene ini mengandung makna yang sesuai dengan ayat AlQur'an yang artinya:

"Dan bersabarlah kamu bersama-sama dengan orang-orang yang menyeru Tuhannya di pagi dan senja hari dengan mengharap keridhaanNya; dan janganlah kedua matamu berpaling dari mereka (karena) mengharapkan perhiasan dunia ini; dan janganlah kamu mengikuti orang yang hatinya telah Kami lalaikan dari mengingati Kami, serta menuruti hawa nafsunya dan adalah keadaannya itu melewati batas" (QS.Al Kahfi:28).

Tidak ada satupun manusia di dunia ini kecuali pernah berbuat dosa, sebaik apapun agamanya, sebaik apapun amalnya nya, sebanyak apapun ilmunya, selembut apapun perangainya, tetap ada kekurangannya. Tetap bersabarlah bersama mereka dan jangan berpaling darinya.

Scane 2: Pelayan Kantin Menjelaskan Bahan Makanan Kepada Rangga yang Seorang Muslim

Rangga :"ini ayam atau bukan?"

Pelayan :"saya tidak mengerti maksud anda".

Rangga :"apa? ini ayam?" (sambil memperlihatkan bahasa tubuhnya)

Pelayan :"bukan, ini bukan daging ayam, ini daging babi. daging ayamnya sudah habis".

Rangga :"saya mau ayam"

Pelayan :"apa anda Muslim?"

Rangga :"ya!"

Pelayan :"saya punya yang lain untuk anda". (sambil menyodorkan sop buah kepada Rangga)

Makna toleransi beragama dalam Scene ini adalah Saling mengerti, telah terjadi dialog antara Rangga dan penjaga kantin yang kebingungan dalam mengerti maksud masing-masing karena bahasa Jerman Rangga yang belum begitu fasih. Namun akhirnya komunikasi keduanya terjalin apik dengan menggunakan bahasa isyarat dan mengerti bahwa Rangga menanyakan ayam yang sudah habis. Mengetahui demikian, penjaga kantin kemudian memberinya buah yang ia anggap halal, sehat dan terbebas dari babi yang haram bagi seorang muslim seperti Rangga. 
Dalam scene ini mengandung makna yang sesuai dengan ayat AlQur'an (QS.Ali Imran: 105) yang artinya:

"Dan janganlah kamu menjadi seperti orang-orang (Yahudi dan Nasrani) yang telah berceri-berai dan berselisihan (dalam agama mereka) sesudah datang kepada mereka keterangan-keterangan yang jelas nyata (yang dibawa oleh Nabi-nabi Allah) dan mereka yang bersifat demikian, akan beroleh azab siksa yang besar".

Scane 3: Rangga menolak tawaran makanan berbahan daging babi dari Stefan

Stefan :"hei Rangga, kemana saja kamu? aku menunggumu di kantin".

Rangga :"aku sedang makan (sambil memperlihatkan sop buahnya)"

Stefan :"apa kamu sedang diet?" (Heran)

Rangga :"tidak, tadi di kantin tidak ada ayam..."

Stefan :"agama kamu ribet banget. tau gak? daging babi itu enak! belum

lagi di Eropa ini, daging babi itu paling murah. udah pernah nyoba?"

Rangga :(menggelengkan kepala) "tidak perlu."

Makna toleransi beragama dalam Scene ini adalah Saling mengerti, telah terjadi adegan antara Rangga dan Stevan saat berada di luar kelas saat jam istirahat. Melihat Rangga hanya memakan buah, Stefan menawarinya untuk memakan daging babi saja yang lezat dan lebih mudah ditemukan di Eropa. Namun Rangga menolaknya dengan dalih bahwa Ia sangat menyayangi Tuhannya dan tidak mungkin melanggar laranganNya, seperti halnya Stevan yang begitu menyayangi anjingnya dan tidak mungkin memakan daging anjingnya seperti yang beberapa orang lakukan terhadap daging anjing. Dan Stevan pun mengerti.

Dalam scene ini terdapat makna yang sesuai dengan ayat Al- Qur'an (QS. Al-Maidah:3) artinya:

"Diharamkan bagimu (memakan) bangkai, darah, daging babi dan (daging) hewan yang disembelih bukan atas (nama) Allah".

Ayat tersebut menjelaskan kepada kita tentang larangan berat memakan daging babi. Dalam hal ini telah dipraktekkan langsung oleh Rangga dalam film tersebut. Dia menolak akan tetapi juga menyindir secara lembut.

Scane 4: Marjaa memberi tahu tempat ibadah

Marjaa :"Khan,Rangga? apa yang kalian lakukan? Prof. Reinhard sudah katakan jangan sembahyang di sini, karena ini ruangan umum, mahasiswa lain dapat terganggu".

Khan :"bukannya semua ruangkan di kampus ini ruangan umum?"

$320 \mid$ JURNAL LISAN AL-HAL 
Marjaa :"bukannya udah disiapin ruangan untuk kalian? (sambil menunjuk tempat) kalian belum tahu? ruangannya ada di sebelah dapur".

Makna toleransi beragama dalam Scene ini adalah Mengakui Hak Setiap Orang, sebagaimana diwujudkan dalam adegan antara Marjaa, Rangga dan Khan ketika Rangga dan Khan hendak menunaikan sholat di sebuah ruangan di kampus mereka, namun seketika Marjaa datang dan menyampaikan pesan Profesor Reinhard bahwa Profesor Reinhard telah menyediakan ruangan khusus untuk mahasiswanya beribadah yang mencerminkan sikap mengakui hak setiap orang untuk menjalankan ibadahnya.

Apabila kita mengetahui bahwa sebenarnya kita mampu berbuat sesuatu untuk menolong kesulitan orang lain, maka segeralah lakukan, segeralah beri pertolongan. Terlebih lagi bila orang itu telah memintanya kepada kita. Karena pertolongan yang kita berikan, akan sangat berarti bagi orang yang sedang kesulitan. Cobalah bayangkan, bagaimana rasanya apabila kita berada di posisi orang yang meminta pertolongan pada kita, Dan sungguh Allah SWT sangat mencintai orang yang mau memberikan kebahagiaan kepada orang lain dan menghapuskan kesulitan orang lain.

Scane 5: Khan tidak merasa yakin dengan tempat ibadahnya
Khan : "sepertinya kita salah ruangan"
Rangga : "ini tempatnya (meyakinkan khan)"
Khan : "kamu serius? ruangan macam apa ini?"
Rangga : "anggap saja ruangan toleransi"
Khan :"toleransi apaan, apa sih yang dipikirkan prof. Rainhard? saya tidak yakin kalo kita sholat disini jadinya sah".

Rangga : "yang penting niatnya bukan tempatnya".

Makna toleransi beragama dalam Scene ini adalah Mengakui Hak Setiap Orang dalam adegan ini disaat Rangga dan Khan memasuki sebuah ruangan yang dipenuhi dengan peralatan ibadah dari berbagai agama, seperti salib, lilin, patung Budha dan dupa. Meski Khan sempat ragu menunaikan ibadahnya di ruangan tersebut namun Rangga dengan sikap lebih terbuka yang mencerminkan sikap mengakui hak setiap orang mampu meneguhkan Khan untuk berbagi tempat ibadah dengan mahasiswa penganut agama lain karena ibadah itu bukan dilihat dari tempatnya tetapi niatnya.

Dalam scene ini mengandung makna sesuai dengan hadits Dari Umar ra, bahwa Rasulullah SAW. bersabda, "Amal itu tergantung niatnya, dan seseorang hanya mendapatkan sesuai niatnya. Barang siapa yang hijrahnya kepada Allah dan Rasul-Nya, maka hijrahnya kepada Allah dan 
Rasul-Nya, dan barang siapa yang hijrahnya karena dunia atau karena wanita yang hendak dinikahinya, maka hijrahnya itu sesuai ke mana ia hijrah.".

Scane 6: Pertemuan pertama Ayse dan Hanum di sekolah

Ayse :"Tante Hanum muslim ya? Tapi ko tante Hanum tidak berkerudung seperti kita?".

Fatma : :Tante Hanum sakit kepala, jadi dia tidak berkerudung”.

Hanum : "iya, tante sakit kepala".

Ayse :"kalau sakit kepala hilang, janji ya tante Hanum pake kerudung?".

Makna toleransi beragama dalam Scene ini adalah Mengakui Hak Orang Lain, dalam adegan ini terjadi pertemuan pertama Ayse dengan hanum, yang dengan polosnya Ayse menanyakan kenapa Hanum yang seorang muslim tidak memakai kerudung layaknya dirinnya. menurut saya pertanyaan seorang bocah seperti Ayse cukup menusuk apalagi untuk Hanum. Akan tetapi dengan kecerdikan Fatma (Ibu Ayse), dia langsung menjawab pertanyaan Ayse dengan lembut dan menghargai Hanum, dengan alasan sedang sakit kepala, Hanum tidak menggunakan kerudung.

Scane 7: Hanum, Fatma dan Ayse sedang menghangatkan diri di Gereja

Hanum :"kok kita masuk gereja Fatma?"

Fatma :"masuk gereja kalo menghangatkan badan tak ada salahnya kan Hanum?"

Makna toleransi beragama dalam Scene ini adalah Agree in disagreement, pada adegan ini ketika Ayse, Hanum dan Fatma melakukan perjalanan menapaki jejak peradaban Islam, mereka dengan sengaja masuk kedalam sebuah gereja untuk menghangatkan diri. Awalnya Hanum merasa heran, kenapa seorang muslim masuk ke dalam gereja, setelah mendapat penjelasan dari Fatma, akhirnya Hanum dapat menerimanya, sesuai dengan hadits yang artinya: "setiap melakukan sesuatu tergantung terhadap niatnya".

Dalam scene ini mengandung makna yang sesuai dengan hadits "Innamal a'maalu bin niyyah" (Sesungguhnya amal itu tergantung dengan niat).

Apa maksud dari hadits tersebut? Maksudnya adalah sahnya suatu amal dan sempurnanya hanyalah tergantung benarnya niat. Oleh karena itu apabila niat itu benar dan ikhlas karena Allah SWT. maka akan sah pula suatu amal dan akan diterima dengan izin Allah Ta'ala. Atau bisa juga maksudnya adalah baiknya suatu amal atau buruknya, diterima atau ditolaknya, mubah atau haramnya tergantung niat.

$322 \mid$ JURNAL LISAN AL-HAL 
Scane 8: Caffe tempat Fatma bercerita asal usul Cappucino

Fatma : :makan lagi ayse rotinya"

Hanum : :jangan ayse..."

Fatma :"kenapa?"

Hanum : :kata bule itu kita makan diri kita sendiri kalo kita makan roti ini."

Fatma : :sudah Hanum biarkan saja, kita punya cara sendiri untuk membalasnya.." (Fatma langsung memanggil pelayan dan menuliskan pesan untuk orang bule tersebut).

Hanum : :kamu pengecut Fatma, kenapa kamu tadi tidak membela diri? Pas agamamu bahkan negara kamu aja dihina oleh mereka".

Fatma :"Hanum..."

Hanum :"kamu bayarin lagi semuanya, kita harus bisa melawan Fatma jangan mau di injek-injek begitu, kita ini harus tunjukin klo kita ini kuat.."

Fatma : :bahwa kita teroris?? Aku juga dulu seperti kamu, hanya butuh penyesuaian saja, lama-lama juga kamu akan merasa hangat dan berfikir jernih dalam menghadapi situasi seperti tadi".

Hanum : :aku bukan malaikat Fatma... aku hanya manusia biasa.."

Fatma :"dengan jilbabku ini, aku wajib menjadi agen Islam yang baik, menjadi berkah, ikhlas dan membawa kedamaian bagi siapa pun termasuk mereka yang tidak beragama Islam".

Hanum : :dan membiarkan kita selalu mengalah?"

Fatma : "kadang itu yang membuat kita menang, lebih baik perang di ranah karya, bukan pedang. kita hadapi dengan hati yah."

Makna toleransi beragama dalam Scene ini adalah Menghormati Keyakinan Orang Lain, pada adegan ini ketika Fatma bersikap baik kepada orang di luar agamanya bahkan yang telah menghinanya. Meskipun sempat tidak sependapat akhirnya Hanum menerima alasan Fatma berbuat baik pada sesama bahkan kepada orang yang telah menyakitinya, karena sesuatu yang buruk tidak selamanya harus dibalas dengan sesuatu yang buruk pula demi menjadi agen mslim yang baik yang membawa kedamaian bagi seluruh umat.

Dalam scene ini mengandung makna yang Sesuai dengan ayat AlQur'an (QS.Fushilat: 34) yang artinya:

"Tolaklah (kejahatan itu) dengan cara yang lebih baik, maka tibatiba orang yang antaramu dan antara dia ada permusuhan seolah-olah telah menjadi teman yang sangat setia". 


\section{Alur Tengah}

Scane 1: Fatma dan Ayse mengagumi Arsitektur gereja

Ayse :"gerejanya bagus yah Ma!"

Fatma :"gereja ini bukan sekedar gereja biasa Ayse, gereja ini terinspirasi oleh menara-menara masjid di Turky".

Makna toleransi beragama dalam Scene ini adalah Agree in disagreement, dalam adegan ini ketika Fatma dan Ayse tengah berdiri mengagumi arsitektur sebuah gereja di Eropa yang arsitekturnya terinspirasi dari menara-menara masjid di Turki. Meskipun gereja merupakan tempat ibadah umat kristiani namun mereka terlihat lega dan bahagia melihat tempat ibadah umat di luar agama mereka dimana inspirator pembangunan gereja tersebut merupakan nenek moyang Fatma dan Ayse di Turki sana.

Dalam scene ini mengandung makna yang sesuai dengan ayat AlQur'an (QS.Ali Imran: 190-191) yang artinya:

"Sesungguhnya dalam penciptaan langit dan bumi, dan silih bergantinya malam dan siang terdapat tanda-tanda bagi orang-orang yang berakal, (yaitu) orang-orang yang mengingat Allah sambil berdiri atau duduk atau dalam keadan berbaring dan mereka memikirkan tentang penciptaan langit dan bumi (seraya berkata): "Ya Rabb kami, tiadalah Engkau ini dengan sia-sia, Maha Suci Engkau, maka peliharalah kami dari siksa neraka".

Yang dimaksud dengan merenungi ayat-ayat Allah, ialah melihatnya, merenungi manfaatnya, sehingga menghasilkan sebuah keyakinan yang mendalam bahwa hanya Allah Azza wa Jalla saja dzat satusatunya yang menciptakan semua itu. Dia-lah satu-satunya yang berhak untuk disembah. Dia-lah satu-satunya yang berhak ditakuti, ditaati, dan hanya Dia yang kita jadikan sebagai petunjuk, sebagai bukti keagungan dan kekuasaan-Nya. Dia tidak menciptakan semua itu dengan sia-sia.

Scane 2: seorang imam di salah satu masjid di Austria bernama Hasyim yang tengah memberikan petuah kepada Rangga dan Hanum

Hasyim :"Tuan Rangga... saya mengerti masalah anda, tapi, sebenarnya tidak serumit itu... karena di Eropa ini... kita hidup damai dan harus belajar tentang toleransi".

Rangga :"Ya".

Hasyim :"Mereka sebagai orang Eropa menghormati Muslim di sini, dan kita juga haus menghormati mereka. Dalam situasi yang anda hadapi ini... Serahkan semuanya kepada Allah... Allah yang menentukan, bukan kita sebagai manusia".

Makna toleransi beragama dalam Scene ini adalah Menghormati

$324 \mid$ JURNAL LISAN AL-HAL 
Keyakinan Orang Lain, pada adegan ini seorang imam di salah satu masjid di Austria bernama Hasyim yang tengah memberikan petuah kepada Rangga dan Hanum terkait masalah yang tengah dihadapi Rangga dalam menghadapi ujian yang bertepatan dengan waktu sholat jum'at yang harus dilaksanakan tiap muslim seperti Rangga. Imam Hasyim pun menasehati Rangga dan Hanum bahwa hidup dalam masyarakat majemuk seperti Eropa haruslah saling hormat menghormati antarumat beragama demi mewujudkan kedamaian dan toleransi antarumat manusia. Karena toleransi yang sehat bukanlah berangkat dari kepercayaan bahwa semua agama dan keyakinan yang berbeda itu sama dan semuanya benar.

Dalam scene ini mengandung makna memantapkan ukhuwah, pertama kali al-Quran mengaris bawahi bahwa perbedaan adalah hukum yang berlaku dalam kehidupan, dan merupakan kehendak Ilahi untuk kelestarian hidup dan mencapai tujuan kehidupan makhluk di pentas bumi.

\section{Alur Akhir}

Scane 1: Hanum membayar Minuman Petugas yang Melarangnya Sujud Di Mezquita

Makna toleransi beragama dalam Scene ini adalah Menghormati Keyakinan Orang Lain, adegan ketika Hanum bersikap baik terhadap petugas yang melarangnya bersujud di Mezquita. Hanum mencoba mempraktekkan apa yang telah Fatma lakukan, menjadi agen muslim yang baik dan membawa kedamaian bagi seluruh ummat.

Dalam scene ini mengandung makna yang Sesuai dengan ayat AlQur'an (QS.Fushilat: 34) yang memiliki penjelasan:

Jika seseorang melakukan keburukan terhadapmu, terlebih khusus lagi jika mereka adalah kerabat-kerabatmu, sahabat-sahabatmu, mereka berbuat buruk kepadamu, baik melalui lisan mereka maupun perbuatan mereka, maka balaslah mereka dengan kebaikan. Jika mereka memutus silaturahmi denganmu, maka sambunglah kembali silaturahmi tersebut. Jika mereka berbuat zholim kepadamu, maka maafkanlah.

Jika mereka menjelek-jelekkanmu, di belakang maupun di hadapanmu, maka jangan engkau jelek-jelekkan mereka kembali, bahkan maafkanlah mereka, dan balas mereka dengan perkataan yang lembut. Jika mereka mengacuhkanmu, tidak mau berbicara denganmu, maka mulailah salam kepada mereka, sapalah mereka dengan baik.

Niscaya jika engkau telah melakukan itu semua, suatu saat nanti mereka akan berbalik menyukaimu, yang sebelumnya memusuhimu, berbalik menjadi teman setiamu. Sesungguhnya hati manusia ada di 
antara jari-jariNya, Dialah yang membolak-balikkan hati manusia sesuai kehendakNya. Sangatlah mudah bagi Allah untuk mengubah benci menjadi cinta ataupun sebaliknya.

Inilah janji Allah dalam FirmanNya, namun sayang beribu sayang, seringkali gengsi kita mengalahkan itu semua, sehingga terlewatilah nasihat dari langit ini untuk kita amalkan.

Scane 2: Khan Membantu Stefen yang selalu Mengejeknya Dan Agama yang Dianutnya

perawat :"Kartunya tidak berlaku lagi, kami tidak bisa memprosesnya".

Khan :"Apakah dia membutuhkan penanganan secepatnya?"

Perawat : (mengangguk)

Khan :"Kau bisa menggunakan kartuku (memberikn kartu asuransi) dia temanku, aku satu-satunya keluarganya di sini".

Makna toleransi beragama dalam Scene ini adalah Menghormati Keyakinan Orang Lain juga terdapat pada adegan saat Khan mencoba melakukan yang terbaik, menolong stefan yang tengah mengalami kecelakaan. Khan bersikap baik meskipun Stefan sering mengolok-olok akan agamanya. Tetapi sebagai seorang muslim, wajib baginya menolong sesama mahluk ciptaan Allah SWT.

Dalam perjalananya menjajaki area ziarah di benua Eropa, mengantarkan Hanum bersua dengan wanita muslim asal Turki di Austria bernama Fatma Pasha (Raline Shah) yang memberikan luasnya kedamaian Islam. Di Paris, Hanum bersua dengan seseorang mualaf, Marion Latimer (Dewi Sandra) yang bekerja untuk ilmuwan di Arab World Institute Paris. Marion tunjukkan bahwasanya Eropa juga yaitu pantulan cahaya kebesaran Islam. Sama halnya dengan sang suami, Rangga Almahendra tiga tahun menunut ilmu pengetahuan di benua Eropa membuatnya jadi lebih cinta dengan Islam. Rangga sadar bahwasanya Eropa banyak menaruh juga Eropa menaruh harta karun histori Islam yang mengagumkan berharganya.

\section{Simpulan}

Film 99 Cahaya di Langit Eropa merupakan contoh hiburan yang bisa dijadikan pembelajaran untuk bisa diambil hikmahnya, dan dari uraian dan analisis yang telah dipaparkan dalam bab-bab sebelumnya, maka dapat diambil kesimpulan bahwa Analisis Narasi Toleransi Beragama Dalam film 99 Cahaya di Langit Eropa, antara lain: Pertama, Film "99 Cahaya Di Langit Eropa" mendeskripsikan realitas kehidupan 
beradaptasi dengan lingkungan yang berbeda agama dan budaya. Melalui analisis narasi model Tzvetan Todorov dalam film "99 Cahaya Di Langit Eropa" diketahui bahwa film tersebut mempunyai tiga tahapan alur,

Kedua, terdapat beberapa makna toleransi beragama yang terkandng dalam film 99 Cahaya Di Langit Eropa yang terdiri dari: a) Mengakui Hak Setiap Orang. Suatu sikap mental yang mengakui hak setiap orang di dalam menentukan sikap atau tingkah laku dan nasibnya masingmasing; b) Menghormati Keyakinan Orang Lain. Landasan akan menghormati keyakinan orang lain adalah berdasarkan kepercayaan; c) Agree In Disagreement (setuju di dalam perbedaan) Perbedaan tidak harus ada permusuhan, karena perbedaan selalu ada di dunia ini, dan perbedaan tidak harus menimbulkan pertentangan; dan d) Saling Mengerti.

\section{DAFTAR PUSTAKA}

Al Munawar, Said Agil, Fiqih Hubungan Antar Agama, Jakarta: Ciputat Press, 2003.

Bordwell, David and Thompson Kristin. Film Art an Introduction, Fourth Edition Singapore: McGraw-Hill Companies Inc, 2006.

Branston, Gill and Stafford Roy, The Media Student's Book. London: Routledge, 2003.

Dadang Kahmad, Sosiologi Agama, Bandung: PT. Remaja Rosdakarya, 2000.

Departemen Agama RI, Al-Qur'an Dan Terjemahan, Bandung: PT. Syaamil Cipta Media, 2004.

Dyayadi, M.T., Kamus Lengkap Islamologi, Yogyakarta : Qiyas, 2009.

Eriyanto, Analisis Naratif: Dasar-dasar dan penerapannya dalam Analisis Teks Berita Media, Jakarta: Kencana Prenada Media Group, 2013.

Gularnic,David G, Webste's World Dictionary of American Language, Cleveland and New York: The world Publising Company, 1959.

Hasyim, Umar, Toleransi dan Kemerdekaan Beragama dalam Islam Sebagai Dasar Menuju Dialog dan Kerukunan Antar Beragama, Surabaya: Bina Ilmu, 1997.

Irawan, Soehartono, Metode Penelitian Sosial, Suatu teknik penelitian bidang kesejahteraan sosial dan ilmu sosial lainnya, Bandung: PT Remaja Rosdakarya, 2004.

Ismail, Faisal, Pijar-Pijar Islam, Pergumulan dan Struktur, Yogyakarta: LESFI 2002.

John Hick, A Christian Theology Of Religions: The Rainbow Of Faiths America :SCM, 1995. 
Karl Heider, National Culture On Screen, Indonesia Cinema: University of Hawaii Press, 1991.

Keraf, Gorys, Argumentasi dan Narasi, Jakarta: PT Gramedia, 2007.

Louis 0. Katsoff dalam Yuni Irawati. 2013. Metode Pendidikan Karakter Islami Terhadap Anak Menurut Abdullah Nasih Ulwan dalam Buku Pendidikan Anak dalam Islam dan Relevansinya dengan Tujuan Pendidikan Nasional. Skripsi tidak diterbitkan. UIN Sunan Kalijaga.

Maryaeni, Metode Penelitian Budaya, Jakarta: Bumi Akasara, 2005.

Masykuri, Abdullah, Pluralisme Agama dan Kerukunan dalam Keragaman, Jakarta: Penerbit Buku Kompas, 2001.

Misrawi, Zuhairi, Alquran Kitab Toleransi, Jakarta: Gramedia Widiasarana Indonesia, 2008.

-.--, Opini Toleransi Verus Intoleransi, Jakarta: Harian KOMPAS, Jum'at 16 Juni 2006.

Moeslim, Abdurrahman, Islam Sebagai Kritik Sosial, Jakarta: Erlangga, 2003.

Muhammad bin Ismail bin Ibrahim al-Bukhary, al-Jami'ah Shahihah, Kitab: Iman, Kairo, Mesir: Maktah as-Salafiyah $1400 \mathrm{H}$.

Mulyana, Deddy, Nuansa-Nuansa Komunikasi Politik dan Budaya Komunikasi Masyarakat Kontemporer, Bandung; PT. Remaja Rosdakarya, 2001.

Porwadarminta, W.J.S., Kamus Umum Bahasa Indonesia, Jakarta: Balai Pustaka, 1986.

Prasista, Himawan, Memahami Film, Yogyakarta: Homerian Pustaka, 2008.

Soekanto, Soejono, Sosiologi Suatu Pengantar, Jakarta: Rajawali Press, 2002.

Stokes Jane, How To Do Media and Cultural Studies (Panduan untuk Melaksanakan Penelitian dalam Kajian Media dan Budaya) Yogyakarta: PT. Bentang Pustaka, 2003.

Sumarno, Marseli. Dasar-Dasar Apresiasi Film, Jakarta: Gramedia Widiasarana Indonesia, 2005.

Thwaites, Tony dkk, Introducing Cultural and Media Studies, Yogyakarta:Jalasutra, 2009. 